\title{
Fungos, fazendeiros e cientistas em luta contra a vassoura-de-bruxa
}

GARLOS HENRIQUE FIORAUANTI"

LÉA VELHO"

\section{Resumo}

Este artigo descreve as interações entre produtores de cacau e pesquisadores acadêmicos, agências de financiamento à pesquisa e atores não-humanos, como fungos em meio à propagação e tentativas de contenção da vassoura-de-bruxa, doença que abateu a lavoura cacaueira da Bahia. A análise deste caso, usando uma abordagem construtivista em sociologia da ciência, procura ilustrar como a produção de conhecimento é multifacetada, ocorre na interface de diferentes espaços institucionais e passa por momentos de resistência e conflitos à medida que incorpora novos atores e transita por tais espaços. Uma lista de discussão pela internet emergiu como meio capaz de aproximar diversos grupos de interessados e de promover a produção coletiva de conhecimento.

Palavras-chave: Vassoura-de-bruxa. Cacauicultura. Teoria Ator-Rede (TAR). Sociologia da Ciência.

* Doutor pelo Departamento de Política Científica e Tecnológica (DPCT) do Instituto de Geociências (IGE) da Universidade Estadual de Campinas (UNICAMP)

** Professora Titular do Departamento de Política Científica e Tecnológica (DPCT) do Instituto de Geociências (IGE) da Universidade Estadual de Campinas (UNICAMP) 


\section{Introdução}

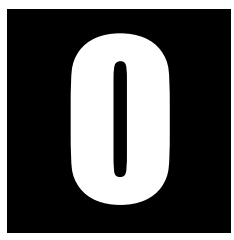

s estudos sobre redes de produção de conhecimento normalmente apresentam os integrantes das instituições formais de pesquisa como protagonistas e atores exclusivos das descobertas científicas ou tecnológicas, com baixa interação e acentuada assimetria de poder com outros grupos de atores; sob essa abordagem, os usuários do conhecimento são normalmente vistos como seres passivos, desprovidos de qualquer criatividade, meros receptores dos resultados de pesquisa. Essa abordagem implica o predomínio do modelo linear de difusão de conhecimento (Latour, 2000, p. 258), segundo o qual, apenas os cientistas produzem conhecimento, em seus laboratórios de pesquisa acadêmica e, em seguida, o transferem para outros grupos sociais, que o incorporam aparentemente sem questionamentos, conflitos ou resistências.

Diferentemente, a percepção de que a produção de conhecimento científico e de artefatos tecnológicos se dá de forma não linear, ou seja, não necessariamente se inicia na academia e chega aos usuários, é central nas abordagens construtivistas sobre ciência e tecnologia'. Apesar de suas diferenças, essas abordagens argumentam que o conhecimento é produzido por meio de interações e negociações entre grupos ou atores sociais distintos, que configuram redes e exercem sua influência no produto final. Não existem atores e nem configurações pré-determinadas para a

\footnotetext{
1 As abordagens construtivistas sobre a produção de conhecimento científico e tecnológico surgiram em meados da década de 70 , e hoje se manifestam em muitas variantes. Todas elas partilham o princípio de que o conhecimento científico e os artefa-tos tecnológicos são produtos sociais e não meros resultados da aplicação do método científico e das escolhas técnicas racio-nais. Para uma visão dos princípios norteadores das principais tendências, ver Knorr-Cetina \& Mulkay (1985). A multiplici-dade de referenciais analíticos que hoje compõem os estudos sociais da ciência e da tecnologia pode ser percebida pela leitura dos artigos publicados no principal periódico da comunidade de praticantes - Social Studies of Science (London: Sage).
} 
constituição dessas redes. Elas se compõem dependendo do evento e a força de cada componente depende de sua capacidade de negociação, de sua habilidade de recrutar aliados e de convencer os outros, dos recursos de cada um (incluindo habilidades e recursos materiais), assim como de estruturas de poder. Durante o trajeto até o conhecimento, a rede não é estável: ela se modifica, agregando ou perdendo atores, assim como se modifica a intensidade das relações entre os atores que a compõem. Portanto, não existem redes estáticas, mas processos contínuos de formação de redes. Para uma dessas abordagens, a Teoria Ator-Rede (ANT), que inspirou esse estudo, os atores que constituem as redes não são, necessariamente, humanos; o que define um ator é sua capacidade de atuar, ou de fazer outras entidades atuarem, na produção do resultado. Assim, um texto, um aparelho que gera inscrições, um microrganismo, assim como as habilidades incorporadas nos pesquisadores, técnicos e gestores do laboratório podem se constituir em elementos da rede, na medida em que interferem no conhecimento ou artefato produzido (Latour, 2005). ${ }^{2}$

Este artigo descreve a interação entre produtores de cacau, pesquisadores acadêmicos, fungos e agências financiadoras de pesquisa, em meio à propagação da vassoura-de-bruxa, doença que prejudicou seriamente a principal região produtora de cacau no Brasil. Ao longo do relato, procura-se mostrar que a produção de conhecimento não é linear, pode emergir em ambientes não-acadêmicos, passando por momentos de resistência e conflitos à medida que incorpora novos atores e transita por espaços diferentes do acadêmico. Evidências como essa são fundamentais para informar a tomada de decisão em política científica e tecnológica, por chamarem a atenção para a importância da participação dos usuários

2 A Teoria Ator-Rede (ANT) desenvolveu-se a partir de um conjunto de estudos empíricos e reflexões teóricas sobre a dinâ-mica de produção de conhecimento científico e de artefatos tecnológicos, sob a liderança de Bruno Latour, Michel Callon e John Law. Latour (2005) faz uma síntese primorosa de toda essa produção. 
nos processos de produção de conhecimento, conforme proposto por Gibbons et al. (2000).

A descrição e análise deste caso se apóiam nos conceitos e nos procedimentos metodológicos propostos pela Teoria Ator-Rede, apresentados de maneira sucinta na seção seguinte.

\section{Difusão e translação de conhecimento}

Em Ciência em Ação, Latour explorou dois conceitos-chave que expressam formas distintas de produção e circulação de conhecimento: os modelos de difusão e de translação. O modelo de difusão, linear e unidirecional, separa ciência e técnica de um lado e sociedade de outro; o sucesso ou fracasso de fatos e artefatos depende da aceitação, indiferença ou resistência de grupos sociais. Há uma cisão entre conteúdo e contexto: os cientistas permanecem no laboratório, do lado de dentro, enquanto do lado de fora estão políticos, investidores, advogados, jornalistas, colegas acadêmicos e usuários do trabalho científico (Latour, 2000: 258-62). O modelo de translação implica uma visão mais ampla e participativa de ciência e tecnologia: a ciência não é mais feita apenas por cientistas, nem a tecnologia apenas por tecnólogos, mas sim por eles e por uma multidão de anônimos que lhes dá reconhecimento social e recursos necessários ao trabalho. Não há mais distinção entre ciência, tecnologia e sociedade, mas apenas cadeias heterogêneas de associações que, de tempos em tempos, criam pontos de passagem obrigatórios (Latour, 2000: 233-4). Há uma constante retroalimentação entre o lado de dentro e o lado de fora do laboratório, de modo que as competências se complementem.

O processo de translação apresenta quatro momentos em que a identidade dos atores, a possibilidade de interação e a margem de manobras são negociadas e delimitadas (Callon, 1996). O primeiro é a problematiza- 
ção: quando emergem o desafio a ser enfrentado e os elementos naturais e sociais indispensáveis para o enredo se abrir. Essa etapa revela os movimentos, interesses e obstáculos que devem ser reconhecidos e as alianças (ou associações) que devem ser feitas entre os grupos de atores. O segundo é o interessamento: um conjunto de ações por meio das quais um dos atores tenta impor seus interesses a outros atores, cuja identidade tenta controlar por meio das estratégias de enfrentamento do problema comum. O terceiro é o de recrutamento de aliados e de definição de papéis, marcado por um jogo de resultados incertos, já que os dispositivos de interessamento não levam necessariamente a alianças, e o sucesso nunca é assegurado. $\mathrm{O}$ quarto momento da translação refere-se à mobilização e às dissidências dos atores em situações que expõem publicamente os representantes dos grupos. Essas etapas não só descrevem um processo que combina elementos sociais e naturais, a serem tratados de modo simétrico para que a análise seja precisa e justa. Também mostram como um grupo de poucos elementos - ou mesmo de um só - obtém o direito de expressar e de representar os muitos atores silenciosos que mobilizaram (Callon, 1986).

Em busca de uma descrição minuciosa deste caso, de acordo com os preceitos da teoria ator-rede (Latour, 2005), identificamos cada uma das etapas do processo de translação de produção de conhecimento por meio de várias estratégias - leitura e análise de documentos e reportagens; entrevistas com produtores de cacau e pesquisadores acadêmicos; e acompanhamento da lista de discussão na internet. As seções seguintes correspondem a cada uma das etapas do modelo de translação aqui apresentado. Convém lembrar que, de acordo com a TAR, referencial utilizado neste estudo, não se faz análise de dados no sentido convencional, mas uma descrição de eventos, atores e procedimentos. A TAR, em vez de apresentar um método de análise de dados, indica como seguir os atores (Latour, 2005: 10-11, 21-25; 52, 55, 68). 


\section{Primeira etapa: o declínio dos cacaueiros}

Os primeiros relatos de sintomas da vassoura-de-bruxa, uma das doenças dos cacaueiros, aparecem nos diários do explorador português Alexandre Rodrigues Ferreira, que a detectou, em 1785 e 1787, em cacaueiros da Amazônia. Causada pelo fungo Moniliophthora perniciosa, deixa os ramos do cacaueiro secos como uma vassoura de bruxa, reduzindo a produção em 50\% a 90\%. Detectada na Bahia em 1989, disseminou-se rapidamente e fez o Brasil sair da posição de terceiro maior produtor de cacau para a de importador (Meinhardt et al., 2008). A produção caiu de 387.662 toneladas, em 1986/87, para 96.038 toneladas em 1999/2000, causando uma perda estimada de 200 mil postos de trabalho ligados à colheita de cacau (Zubaib et al, s/d).

Os procedimentos agrícolas que haviam sido propostos pelo Centro de Pesquisas (Cepec) da Comissão Executiva do Plano da Lavoura Cacaueira (Ceplac), a partir dos anos 90, para deter o avanço da vassourade-bruxa - rebaixamento da copa das árvores, aplicação de fungicidas e implantação de clones (variedades supostamente resistentes à doença) nas árvores mais antigas - não funcionaram. Produtores entrevistados para a realização deste artigo comentaram que as medidas propostas só pioraram a situação e fizeram a doença se espalhar ainda mais, já que o fungo se alojava exatamente nos ramos que cresciam após a poda. Por estarem atrelados a empréstimos bancários, esses procedimentos aumentaram a dívida dos produtores, que já haviam perdido as principais fontes de renda ao cortarem as árvores produtivas e implantarem clones que demorariam anos até frutificarem. Muitas variedades de clones não se mostraram efetivamente resistentes no campo e outras não frutificaram, por serem sexualmente incompatíveis e, portanto, incapazes de polinizar a própria variedade. A produtividade caía e as dívidas cresciam, em meio à desconfiança e ao ceticismo dos fazendeiros. 
Um ator não-humano, o fungo, havia desestabilizado uma rede de atores constituída em torno do cacau, unindo produtores, Ceplac, bancos, empresas processadoras de cacau e consumidores. $\mathrm{O}$ modo linear de produção de conhecimento, que partia da Ceplac e seguia para os produtores, não havia funcionado. A incapacidade dos pesquisadores da Ceplac em resolver o problema e a gravidade da situação, medida em termos de queda de produtividade e de empregos, motivaram outros atores a agirem por si, em busca de novas formas de deter a vassoura-de-bruxa. O produtor de cacau Edvaldo Magalhães Sampaio começou, em 1999, a testar novas formas de combater a vassoura-de-bruxa que chegava a suas fazendas no interior da Bahia. Paralelamente, um pesquisador da Universidade Estadual de Campinas (Unicamp), Gonçalo Amarante Guimarães Pereira, organizou em 2000 uma rede de pesquisa para estudar o genoma (conjunto de genes) do fungo causador da doença. Ambos se encontraram em 2005, com visões complementares sobre as possibilidades efetivas de combate à doença dos cacaueiros.

\section{Segunda etapa: o empirismo de um produtor de cacau}

Residente em Gandu, município próximo a Ilhéus, o centro produtor de cacau no Brasil, Edvaldo Sampaio havia trabalhado como agrônomo na Ceplac antes de ser produtor de cacau (Sampaio, 2008: 18-34). Ele cultivava cacau em quatro fazendas que havia comprado no sul da Bahia quando começou a ser acossado pela vassoura-de-bruxa, como os outros produtores da região. Em busca de resultados melhores, Sampaio fez adaptações nas medidas de controle da doença propostas pela Ceplac, selecionando e cultivando a seu modo as variedades de clones resistentes ao fungo, mas não foi o bastante para deter a queda de produção. 
Disposto a enfrentar o problema com base em seus próprios conhecimentos de agronomia, Sampaio começou em 1999 a testar e a adotar gradativamente em suas fazendas uma série de medidas agronômicas que, a seu ver, poderiam proteger os cacaueiros do ataque do fungo: ele induzia o florescimento do cacaueiro por meio de cortes superficiais no caule, reforçava a adubação e antecipava a poda, de modo a colher os frutos ainda no primeiro semestre de cada ano, antes do ataque dos fungos, mais intenso no segundo semestre. Como resultado desse conjunto de medidas, a produtividade das fazendas de Sampaio começou a se recuperar, à medida que o fungo deixava de contaminar os cacaueiros.

Sampaio não conseguiu expandir de imediato o uso de suas técnicas, como pretendia. Não tinha credibilidade entre outros produtores, que o acusavam de "fazer tudo errado" na medida em que ele modificava as regras da Ceplac sem obter benefícios dos ajustes que fazia (Fioravanti, 2006). Seus argumentos eram puramente empíricos - o método que havia desenvolvido funcionava e seus cacaueiros estavam livres da doença que ainda era comum na região - e não bastaram para atrair o interesse de outros produtores de cacau. Como não haviam sido monitorados, os resultados que obtinha, mesmo que pudessem ser vistos, poderiam ser atribuídos a circunstâncias como a qualidade das terras ou a localização das fazendas de Sampaio, um pouco afastadas do centro de produção e de maior disseminação da doença. Mesmo se quisessem, os outros fazendeiros teriam dificuldade para adotar as novas técnicas, porque a maioria deles estava endividada com os bancos e suas plantações encontravam-se bastante degradadas, muitas já abandonadas. Sampaio, mesmo colhendo bons frutos em suas fazendas, permaneceu isolado por muitos anos, incapaz de estabelecer novas conexões que expandissem o uso do método que havia criado. 
Só alguns anos depois é que as conclusões de uma rede de pesquisa do genoma que emergiu em Campinas, no estado de São Paulo, Ihe dariam credibilidade e permitiriam a disseminação das técnicas de combate ao fungo que ele havia desenvolvido.

\section{Terceira etapa: o fungo no laboratório}

As redes de pesquisa científica ganharam visibilidade no Brasil a partir de 1997, por meio de projetos de seqüenciamento do genoma de microrganismos, animais e plantas. O primeiro deles, concluído em 1999, reuniu 34 laboratórios do estado de São Paulo com o propósito de seqüenciar o genoma da bactéria Xylella fastidiosa, a causadora de uma doença que então atacava severamente as plantações de citros principalmente no estado de São Paulo (Simpson et al.). Nos seis anos seguintes, emergiram 22 outros projetos de pesquisa de genomas, de abrangência estadual, regional ou nacional, com a participação marginal de laboratórios de empresas (Camargo e Simpson, 2003). O modelo linear de produção de conhecimento predominou nestas redes de pesquisa, privilegiando as instituições de pesquisa, com escassa interação entre os potenciais beneficiários do conhecimento.

Em 2000, um dos quase 200 pesquisadores que haviam participado do sequenciamento do genoma da Xylella fastidiosa, Gonçalo Pereira, se preparou para ajudar no controle da vassoura-de-bruxa. Seu plano era organizar uma equipe de pesquisadores acadêmicos e estudar o genoma do fungo causador da vassoura-de-bruxa. Como coordenador do Laboratório de Genômica e Expressão (LGE) do Instituto de Biologia (IB) da Unicamp, Pereira argumentava que o conhecimento a ser obtido sobre o fungo e a doença poderia embasar o desenvolvimento de estratégias de combate à doença mais eficientes do que as adotadas até então, com base apenas 
na experimentação e sem resultados efetivos (ele ainda não conhecia o trabalho de_Edvaldo Sampaio). O governo do estado da Bahia aceitou sua proposta de trabalho e liberou $\mathrm{R} \$ 1,2$ milhão para o Projeto Genoma da Vassoura-de-Bruxa, que no ano seguinte recebeu mais RS\$1,3 milhão do governo federal, reunindo a equipe da Unicamp e de laboratórios de universidades e centros de pesquisa da Bahia (Pereira, 2006).

Enquanto Sampaio lutava contra o fungo em suas fazendas, Pereira fez de seu laboratório na Unicamp um centro da pesquisa contra a vassoura-de-bruxa no Brasil. Trouxe o fungo Moniliophthora perniciosa do campo para o laboratório e o domesticou, descobrindo como poderia ser cultivado em condições controladas (Meinhardt et al, 2006). As equipes da Unicamp e as dos outros laboratórios da rede trataram de investigar em detalhes o comportamento e o desenvolvimento do fungo e da doença. A identificação dos genes do fungo e de suas respectivas funções, aos poucos elucidou os mecanismos bioquímicos pelos quais o fungo atacava e a planta se defendia antes de começar a morrer. Essas informações serviram para construir uma espécie de mapa da doença, mostrando como o fungo agia e que reações acionava desde a contaminação da planta. Esse mapa indicou rotas bioquímicas na forma de genes, enzimas ou proteínas que poderiam ser bloqueadas para impedir o desenvolvimento do fungo na planta (Scarpari, 2005).

Como a Ceplac havia silenciado, sem outras propostas de ação contra a vassoura-de-bruxa, e Sampaio era ainda muito pouco conhecido, o laboratório da Unicamp tornou-se o primeiro ponto de passagem obrigatório da rede de inovação que começava a se formar.

Pereira saiu em busca de aliados que ajudassem a testar as estratégias de ação contra o fungo que emergissem de seu grupo de pesquisa. A partir de 2000, quando obteve o primeiro financiamento para levar adiante a pesquisa sobre o fungo, ele começou a comparecer a palestras, reuniões e 
debates com produtores de cacau, expondo-lhes seu plano de desenvolver formas logicamente fundamentadas - e não apenas empíricas, como até então - de combate à doença dos cacaueiros (Pereira, 2006).

Como Pasteur ao longo da pesquisa e do desenvolvimento da vacina contra o antraz na França (Latour, 1983), Pereira teve de capturar interesses, vencer resistências, fazer-se indispensável e estabelecer alianças para que seu trabalho vencesse as paredes do laboratório e chegasse aos usuários. As conversas evidenciaram o descrédito das instituições de pesquisa, já que a Ceplac não havia conseguido resolver a disseminação da vassoura-de-bruxa, e a desconfiança dos fazendeiros, que viam Pereira como um cientista de uma universidade paulista que não conhecia os problemas reais da cacauicultura na Bahia. Ele não era, porém, tão forasteiro quanto parecia. Nascido em Salvador, capital da Bahia, e formado em 1987 em engenharia agronômica pela Universidade Federal da Bahia (UFBa), Pereira havia testemunhado o auge da cultura cacaueira. Sua motivação para entrar na luta contra o fungo, que a muitos fazendeiros parecia perdida, tamanha a dimensão das perdas, resultava de uma visita recente à Bahia, em que havia se impressionado com a devastação e o impacto econômico causados pela vassoura-de-bruxa.

Pereira integrou-se efetivamente ao grupo que procurava conquistar, tornando-se, ele próprio, um fazendeiro. Em dezembro de 2001, ele e dois sócios compraram uma fazenda de 900 hectares, em Ilhéus, por um preço 40 vezes menor do que o mínimo que seria exigido duas décadas antes. Desse modo, ele pretendia provar que as plantações de cacau poderiam realmente se recuperar, desde que bem cuidadas e bem administradas, e, ao mesmo tempo, ter à mão plantações de cacau em que ele próprio pudesse testar, com autonomia, as novas formas de combater o fungo, caso nenhum outro fazendeiro se interessasse em por em campo as estratégias de ação que pretendia elaborar. A fazenda em Ilhéus seria assim uma extensão do laboratório da Unicamp (Pereira, 2006). 
Valorizando a interação com os produtores de cacau, de quem precisava para seguir adiante com seu propósito de pôr em campo novas formas de combater a vassoura-de-bruxa, Pereira procurou afastar-se do modelo linear de difusão de conhecimento, em que os especialistas de instituições de pesquisa como a Ceplac apresentavam aos fazendeiros soluções prontas e incontestáveis. Desse modo, ele tentava evitar que a rede de pesquisa sobre o fungo causador da vassoura-de-bruxa fosse apenas mais uma rede de pesquisa acadêmica, com escassos resultados concretos.

Pereira ampliou a rede de pesquisa e as perspectivas de diálogo com os fazendeiros trazendo para a Unicamp em 2003 uma lista de discussão pela Internet e integrando-a à rede de pesquisadores acadêmicos. Chamada simplesmente de lista do cacau, essa lista estava por ser extinta porque o produtor de cacau que a havia criado em 1999 não tinha como cobrir sozinho o custo de manutenção. A transferência da lista para um computador da Unicamp eliminou os custos e permitiu a expansão da lista, que passou de 100 integrantes no início de 2000 para 720 em agosto de 2006. Aos produtores que formavam o núcleo inicial, integraram-se outros atores ligados à pesquisa, à produção ou à comercialização de cacau: especialistas de instituições de pesquisa, professores universitários, ambientalistas, processadores, exportadores, empresários, políticos, funcionários do Ministério da Agricultura e do Senado, jornalistas e fabricantes de equipamentos ou de chocolate.

Por meio da lista de discussão, os produtores de cacau ofereciam o conhecimento prático que haviam acumulado e colaboraram com os pesquisadores acadêmicos, orientando a descoberta e o reconhecimento de propostas concretas contra essa doença dos cacaueiros. A lista transformou a rede de pesquisa, puramente acadêmica, em uma rede de inovação, voltada à resolução de um problema comum, a vassoura-de-bruxa. A rede de inovação quebrou as barreiras de comunicação entre grupos 
de atores habitualmente distantes e facilitou o afloramento, o debate, a seleção e a disseminação de propostas concretas para proteger as plantações de cacau do Brasil contra a doença mais devastadora que já haviam enfrentado. Essa forma de trabalho integrado expressa um arranjo possível do modelo de translação, em que não há mais distinção entre ciência, tecnologia e sociedade, como no modelo de difusão, e outros atores, não só os cientistas profissionais, são essenciais para novos conhecimentos emergirem (Latour, 2000, p. 233-4).

A lista do cacau facilitou a busca de respostas contra a vassourade-bruxa. Em primeiro lugar, por ter ampliado o corpo de produtores de conhecimento, na medida em que acolheu e valorizou os relatos dos produtores sobre o desempenho dos clones ou de novas técnicas de manejo do solo ou dos cacaueiros. Antes distantes, os agricultores passavam a contar com uma forma de comunicação direta e instantânea, por meio da qual podiam trocar experiências - o malogro das estratégias iniciais motivou-os a testar soluções próprias. Em segundo lugar, por ter fortalecido os compromissos dos pesquisadores com a busca de soluções contra a vassoura-de-bruxa; os feedbacks contínuos explicitaram a demanda, direcionaram a pesquisa de laboratório e facilitaram a substituição da visão linear e hierárquica de produção de conhecimento por uma estrutura horizontal. Como resultado, fazendeiros e pesquisadores começaram a interagir, motivados pela crise econômica e social decorrente da queda da produção de cacau. A lista do cacau funcionou como ator no processo, na medida em que teve papel fundamental na interação entre cientistas profissionais nos laboratórios e produtores no campo.

O espaço para os usuários participarem da busca de alternativas contra a vassoura-de-bruxa estava aberto - e foi aproveitado. Em agosto de 2005, Sampaio enviou para a lista uma série de fotos de cacaueiros de suas fazendas, todos repletos de frutos e sem sinais da doença. Ele pre- 
tendia apresentar os resultados a que havia chegado por meio de técnicas que ele próprio havia adotado e que até então não haviam atraído o interesse de outros produtores de cacau.

Pereira, como coordenador da lista de discussão, leu a mensagem, viu as fotos e pediu mais explicações a Sampaio. Em seguida, Pereira viu no trabalho de Sampaio o resultado já pronto de uma estratégia de ação que havia apenas imaginado. Com base no mapa sobre o desenvolvimento da doença, elaborado a partir das informações sobre genes e proteínas que o fungo acionava para crescer nos cacaueiros, Pereira havia concluído que uma forma de antecipar a colheita e escapar do fungo era justamente induzir o florescimento das árvores produtoras de cacau - como Sampaio havia feito. Meses antes, Pereira havia testado essa técnica, mas aplicando hormônios vegetais nos cacaueiros de sua própria fazenda, em um experimento que mobilizara cerca de 100 pessoas, mas que não deu certo.

Ao ler a mensagem e ver as fotos das árvores, Pereira soube ver, com base no que já conhecia sobre o fungo, que Sampaio havia encontrado - e já testado, com resultados positivos - uma saída contra a vassoura-debruxa. Sampaio (2008, p. 51) descreve:

Na mesma época, Edno [Edno Querino Câmara, integrante da lista] colocou algumas imagens na lista do cacau, nem assinante da lista eu era quando recebi um telefonema de Gonçalo, exclamando: "Rapaz, eu vi um risco no pé de cacau, o que é isso?" Um roletamento. "Quem mandou você fazer?" Ninguém. Fiz para aumentar minha produção. "Não é possível! Se você fez o que estou pensando, você fez uma descoberta para a ciência, o mundo inteiro queria fazer e não sabia como!"

Pereira disparou uma mensagem na lista apresentando essa conclusão, com base no conhecimento que havia adquirido ao longo do estudo do genoma do fungo. Ele pediu mais detalhes sobre como Sampaio tratava os cacaueiros e em seguida o visitou. Sampaio (2008, p. 51) descreve: Afir- 
mei [para Pereira]: Minhas plantas são educadas; produzem como eu quero. [Pereira comentou:] Não. Você faz a sincronização da produção. Sampaio ganhava reconhecimento e tornava-se o protagonista da rede de inovação contra a vassoura-de-bruxa. Sampaio ganhava explicações científicas para a eficácia de suas técnicas e Pereira, uma demonstração de que o conhecimento sobre o desenvolvimento do fungo poderia efetivamente ser útil. As duas linhas de trabalho convergiram e se complementaram.

As mensagens que circularam na lista de discussão nessa época indicam que Pereira não hesitou em reconhecer que Sampaio havia encontrado uma alternativa consistente e de baixo custo contra a vassoura-debruxa, nem em aprender com o agricultor - agrônomo como ele, mas sem o status e o reconhecimento de professor e pesquisador universitário. Rapidamente se fez um espaço de troca de conhecimentos que facilitou o debate e a translação das descobertas entre os produtores de cacau.

\section{Quarta etapa: os movimentos da rede}

Pereira, ao verificar que os testes empíricos de Sampaio guardavam uma lógica científica, desloca o centro de ação - o ponto de passagem obrigatório - da rede de inovação contra a vassoura-de-bruxa, do laboratório da Unicamp para as fazendas de Sampaio, convertidas em campo de demonstração das possibilidades de controle efetivo do fungo (Santos e Oliveira, 2005; Fioravanti, 2006). Se num primeiro momento Pereira representava os cientistas e falava aos produtores, num segundo Sampaio representava os produtores e então ele é que falava aos cientistas. O sentido da ação se inverteu, consolidando a interação e a perspectiva de produção coletiva de conhecimento, que até então havia corrido em paralelo - pesquisadores nos laboratórios e produtores em suas fazendas, com enfoques distintos, embora complementares. 
Convertido em protagonista da produção de conhecimento, Sampaio começou a disseminar suas técnicas e conclusões para os produtores que ainda lutavam contra a doença. Foi então sua vez de capturar interesses, vencer resistências, fazer-se indispensável e estabelecer novas alianças. A despeito dos resultados exibidos nas fotografias das árvores saudáveis de suas fazendas, Sampaio teve de apresentar, por solicitação dos integrantes da lista do cacau, longas explicações com os detalhes - enfim, a lógica - dos procedimentos que havia adotado. Suas fazendas começaram a ser visitadas por outros produtores e por pesquisadores interessados em observar in loco o que ele havia feito. Seus experimentos empíricos começaram a reger as pesquisas coordenadas pela Unicamp, que procuravam interpretar, ajustar ou complementar as técnicas adotadas em campo. Pereira foi o primeiro a solicitar a Sampaio permissão para que uma de suas alunas acompanhasse o desenvolvimento dos cacaueiros tratados com o conjunto de medidas que se tornava público. Em agosto de 2006, uma equipe do Centro de Pesquisas da Ceplac anunciou que iniciaria em uma fazenda próxima a Ilhéus, com a consultoria de Sampaio, uma série de experimentos controlados com o objetivo de testar, separadamente, cada uma das técnicas propostas para deter a vassoura-de-bruxa (Fioravanti, 2006).

As medidas testadas por Sampaio ainda ganhavam adesões um ano depois de terem sido anunciadas publicamente: a lista do cacau é fértil em relatos de produtores que visitaram as fazendas de Sampaio e se impressionaram com os resultados, a ponto de escreverem que pretendem aplicar os mesmos cuidados em suas próprias terras. Mas também enfrentavam resistência de produtores que argumentavam que essas técnicas apresentavam custos elevados e só poderiam ser aplicadas em condições de solo e de clima específicas, diferentemente do que Sampaio assegurava. Segundo ele, o fato de essas medidas funcionarem em suas quatro fazendas - duas sob um clima úmido como o de Ilhéus, a principal região 
produtora de cacau, e duas sob um clima mais seco, mais ao norte - demonstrava que as medidas funcionariam sob diferentes ambientes.

Sampaio conseguia mais visibilidade. Em 15 de março de 2007 o suplemento agrícola do jornal O Estado de São Paulo contava que a Bahia havia vencido "a pior doença do cacau" e que Sampaio, no ano anterior, havia recebido 700 visitantes em uma de suas fazendas para mostrar o que havia feito (Melo, 2007). Em 22 de julho de 2007, o Globo Rural, o principal programa sobre agricultura na televisão brasileira, contou de suas descobertas, de seu trabalho com a Unicamp e de outros produtores que haviam seguido suas recomendações e reduzido a vassoura-de-bruxa.

O terceiro deslocamento - do campo para os laboratórios - encontra resistências, derivadas das próprias características da cacauicultura baiana desde que a vassoura-de-bruxa se manifestou, como o desinteresse dos produtores em investir nas plantações, a baixa produtividade e o elevado endividamento bancário (Dias, 2006). Hartmann (2008) atribui à "falta de tratos culturais e investimentos nas lavouras, resultante da descapitalização profunda dos cacauicultores, aliada a condições climáticas desfavoráveis" a queda na produção de cacau na Bahia, pelo segundo ano seguido, de 114.705 toneladas em 2006 para 102.973 toneladas em 2007; o resultado de 2007 aproximou-se ao de 1999, auge da vassoura-de-bruxa, quando a Bahia apresentou a menor produção dos 45 anos anteriores, com apenas 101.234 toneladas. As propostas para renegociação das dívidas e retomada da produção, que o governo federal havia anunciado em setembro de 2007, o PAC (Programa de Aceleração do Crescimento) da Agricultura, continuavam incertas. De 2006 para 2007, a produção da Bahia havia passado de $81,10 \%$ para $74,67 \%$, enquanto a do Pará crescera de 15,04\% para 20,55\% e a de Rondônia, de 0,61\% para 1,37\% (Hartmann, 2008).

A equipe da Unicamp, ao validar em campo a abordagem proposta por Sampaio, ajudou a consolidar uma solução técnico-científica que mo- 
bilizou outros produtores e serviu de argumento para a renegociação da dívida dos fazendeiros com o banco. A rede de inovação mobilizou também a rede inicial, centrada na Ceplac, que, por fim, reagiu. Em 17 de março de 2008, o jornal A Tarde noticiou uma nova técnica contra a doença, chamada indução de resistência sistêmica para o controle da vassoura-de-bruxa em cacaueiros, que vinha sendo estudada havia 12 anos por um agrônomo da Ceplac, Deraldo Ramos Vieira (Oliveira, 2008). Vieira começou a dar palestras seguidas para disseminar essa técnica, que consiste na ativação das defesas da planta por meio de uma única injeção de 2,5 mililitros de sacarose (açúcar) no tronco de cada cacaueiro infectado e teria reduzido em $80 \%$ a infecção pelo fungo causador da vassoura-de-bruxa (Bahia Já, 2008; Brito, 2008). Promovida intensamente pela Ceplac (2008a), essa técnica rapidamente ganhou mais espaço no noticiário dos jornais da Bahia e de estados vizinhos como o Espírito Santo, onde a vassoura-de-bruxa também é um grave problema agrícola (Coimbra, 2008). A despeito dos resultados alardeados, os autores deste trabalho não encontraram na base Scielo nenhum artigo científico atestando os resultados apresentados nem o currículo acadêmico de Vieira na base Lattes.

Uma página da Ceplac na internet remetia a três resumos de trabalhos apresentados em congressos científicos em 2000, 2001 e 2006. ${ }^{3} \mathrm{O}$ trabalho de 2006, que chegou à lista de cacau em março de 2008, reconhecia que

3 VIEIRA, Deroaldo et al. Efeito de doses crescentes de glicose nos teores de amido e açúcares redutores dos clones de Theo-broma cacao L. SCA 6 e UF 613, inoculados com Crinipellis perniciosa e possíveis interações com mecanismos de resistên-cia. 13을 Congresso Internacional de Pesquisas em Cacau, Kota Kinabalu, Malásia, 2000; VIEIRA, Deroaldo et al. Efeito de doses crescentes de glicose nos teores de açúcares solúveis totais dos clones de Theobroma cacao L. SCA 6 e UF 613, inocu-lados com Crinipellis perniciosa e possíveis interações com mecanismos de resistência. VIII Congresso Brasileiro de Fisiolo-gia Vegetal, Ilhéus, Bahia, Brasil, 2001; VIEIRA, Deroaldo et al. Indução de resistência sistêmica para o controle da vassoura-de-bruxa Crinipellis perniciosa(Stahel) Singer em cacaueiros (Theobroma cacao L.) dos clones ICS 1 e CCN 51. 15ํㅡ Confe-rência Internacional de Pesquisas em Cacau, São José, Costa Rica, 2006. Disponíveis em: <http://www.ceplac.gov.br/radar/inducao>. Acesso em: 9 dez. 2008. 
Apesar da eficiência dos agroquímicos no controle de doenças de plantas, o surgimento de populações de patógenos resistentes a defensivos agrícolas, além de dificultar o controle, propicia grandes prejuízos tanto à industria daquelas substâncias quanto ao produtor. Outro aspecto referente à utilização desses defensivos em larga escala no controle de enfermidades de plantas, é o desequilíbrio ecológico que provoca no meio ambiente, afetando outros organismos não envolvidos nos patossistemas.

Uma das conclusões do trabalho de 14 páginas era:

Açúcares além de regularem a expressão de genes do metabolismo primário, também regulam a expressão de genes específicos de ferimentos, como inibidores de proteinase e lipoxigenase, proteínas relacionadas com patogênese.

Em uma mensagem enviada à lista no dia 11 de março de 2008, Pereira considerava supérfluo o uso da injeção de sacarose, que, segundo um dos produtores de cacau, havia sido eficiente, mas fora utilizada em conjunto com as técnicas preconizadas por Sampaio. Em seguida, Pereira lembrava que medicamentos em geral tinham de passar por testes rigorosos antes de ser aprovados para uso amplo:

Informo aos colegas menos familiarizados com esse processo de geração de tecnologia, que o caminho normal para novas técnicas é a experimentação, a redação de artigos científicos, a avaliação pelos pares e só então a liberação. Nada disso tem sido feito e toda a questão tem sido tratada de forma alegórica, completamente inadequada. [...] O ideal seria estabelecer um diálogo na lista, sem medo e com total transparência. A politização dessas questões tem gerado um nítido constrangimento em diversos colegas de conversar livremente sobre esses assuntos, sendo preferível tratar no particular. [...] Sugiro que perguntem, duvidem, lembrem-se que estão tratando de negócios e de uma cultura permanente, cujos erros são cobrados por muito tempo. 
Na mesma mensagem, Pereira analisava o trabalho de Vieira e Valle de 2006, argumentando que os dados apresentados não eram suficientes para mostrar que a sacarose tem efeitos contra o fungo causador da vassoura-de-bruxa: E seria importantíssimo que esses resultados fossem publicados em uma revista científica, com julgamento entre os pares. Ou seja, para ser julgado entre especialistas e não entre produtores, que por mais qualificados que sejam, não têm o treinamento necessário para perceber o que é ou não um resultado/conclusão qualificada.

A lista abrigou continuamente mensagens de produtores relatando a eficácia das injeções de sacarose em suas próprias fazendas e de outros que se mantinham céticos. Enquanto essa técnica de combate ao fungo carecia de estudos experimentais controlados que atestassem sua eficácia, as medidas de Sampaio ganhavam o respaldo tanto de outros produtores que conseguiam reproduzir os mesmos resultados, quanto dos estudos feitos nos laboratórios da rede de pesquisa coordenada pela Unicamp e publicados em revistas científicas internacionais; o genoma do fungo causador da vassoura-de-bruxa, publicado em 2008, detalhou os mecanismos de sobrevivência do fungo (Mondego et al., 2008; Meinhardt et al., 2008). Em 12 de março de 2008, uma das integrantes da lista propunha:

Vamos apoiar os dois e pressionar a CEPLAC para que faça o seu trabalho, DESENVOLVA A PESQUISA, TESTE. Por falar em pesquisa, a CEPLAC tem o TRICOVAB, que também funciona. GOSTARIA DE SABER COMO É QUE ELE VAI SER PRODUZIDO E COMERCIALIZADO. Para que é que serve a pesquisa se não temos acesso aos resultados?

Outros participantes da lista viam nessa disputa entre as duas técnicas agronômicas uma tentativa de manchar a imagem da Ceplac, ressaltando apenas os erros da instituição e deixando de lado os acertos. Em novembro de 2008, a Direção da Ceplac distribuiu uma Nota à Imprensa (Ceplac, 2008b) motivada por entrevistas de Pereira, ressaltando que a técnica de 
indução sistêmica é uma linha de pesquisa bastante estudada, com resultados amplamente conhecidos na literatura científica, em diversas espécies, tendo revelado diversos agentes indutores, dentre os quais a sacarose. A Nota destaca também que essa técnica representava uma linha de pesquisa de Vieira, há cerca de oito anos na Ceplac, fazendo parte, inclusive, de seu trabalho de tese de mestrado. Os dois últimos itens da Nota:

7. A pesquisa participativa, com o envolvimento de técnicos e produtores, freqüentemente questionada pela Academia, é uma experiência estimulada pela CEPLAC, por acreditar que não podemos abrir mão da experiência e capacidade crítica de todos, principalmente dos produtores de cacau, cujo maior testemunho tem sido dado pelo produtor/agrônomo Edivaldo Sampaio, como reconhece o próprio Dr. Gonçalo Pereira;

8. A CEPLAC não alimenta discórdias técnicas por ter como valor o debate construtivo e acreditar que a construção do conhecimento deve ser um processo crítico, democrático e transparente. Assim sempre estará aberta à contribuição de todos quantos possam contribuir e se legitimar nessa construção, de forma isenta e sem personificações desnecessárias.

O comunicado tentava fechar o debate sobre a eficácia da técnica de indução à resistência. Em 3 de dezembro de 2008, respondendo a uma dúvida de um produtor, Pereira comentava que as injeções de sacarose, com base nos dados à mão, não apresentavam efeito claro e que ainda se encontrava em uma etapa muito preliminar de testes, assim como o roletamento, uma das técnicas adotadas por Sampaio. Por fim, ele concluía que a indução de resistência:

Não é, de forma alguma, um divisor de águas no combate a vassoura de bruxa e não se justifica, de jeito algum, os recursos aplicados na divulgação da técnica. Esse movimento, quando vindo de cacauicultores, pode ser encarado como algo político, com motivações diversas. Mas vindo de um orgão oficial, isso é uma irresponsabilidade, passível de punição. [...] Infelizmente não existe mágica. Já sabemos o que fazer, 
mas trata-se de trabalho árduo e com custos. Entretanto, os princípios são facilmente aplicáveis e compreendendo-os podemos com facilidade adaptar o que já fazemos.

\section{Conclusões}

Esse relato indica que a resistência a propostas de ação protagonizadas por quem não participa dos grupos habituais de produção de conhecimento pode ser maior quanto maiores as possibilidades de mudança trazidas pelas novas abordagens, quanto maior a distância entre amadores e profissionais, e quanto maior o risco de novos personagens emergirem como produtores de conhecimento. As propostas de Edvaldo Sampaio, embora avalizadas pela equipe da Unicamp, representavam outra forma, mais trabalhosa, de lidar com os cacaueiros e outros papéis, mais pró-ativos, para os proprietários rurais, além de exibirem os limites das instituições formais de pesquisa. As reações da Ceplac sugerem que propostas levantadas por atores marginais aos circuitos previamente estabelecidos de produção de conhecimento podem gerar resistências e oposições de resultados incertos.

A Ceplac, instituição tradicional de pesquisa cacaueira cuja atuação se mostrou evidente no início e no final deste relato, mostrou-se interessada em manter o monopólio do conhecimento, a partir do qual os produtores poderiam agir para tratar suas plantações e obter financiamentos bancários. Durante todo o tempo, a Ceplac adotou o modelo de difusão de conhecimento, sem permitir questionamentos, interações ou negociações: os produtores deveriam apenas fazer o que seus técnicos determinassem como a melhor forma para evitar a vassoura-de-bruxa. Diferentemente, a equipe da Unicamp adotou o modelo de translação do conhecimento, reconhecendo o conhecimento dos produtores e interagindo com eles. 
A divergência entre as duas abordagens de produção e uso do conhecimento acentuou-se no final, quando a Ceplac reconheceu, mas não validou, o trabalho da Unicamp e, evitando controvérsias, propôs algo mais simples e prático que as medidas desenvolvidas por Sampaio e Pereira. As reações publicadas na lista do cacau indicaram que ao menos parte dos produtores preferiu adotar as medidas que apresentavam menor embasamento científico, mas facilitavam o acesso ao crédito bancário de que necessitavam para quitar suas dívidas. A esmerada argumentação científica do grupo da Unicamp não conseguiu se sobrepor ao apego dos produtores de cacau a uma instituição tradicional e detentora de poder econômico, que intermediava o acesso aos bancos. A multiplicidade de formas de combate à vassoura-de-bruxa não implicou liberdade de ação, porque assentava-se tacitamente no receio dos produtores - ou ao menos dos mais tradicionais - de aceitar novas autoridades, novas fontes de conhecimento ou novas abordagens de trabalho.

Mesmo que os procedimentos adotados por Sampaio não sejam validados pela Ceplac, nem adotados como padrão pelos outros produtores de cacau, fizeram emergir um espaço de produção coletiva e de disseminação de conhecimento: a lista do cacau. Os pesquisadores da rede de pesquisa do genoma da vassoura-de-bruxa acolheram o conhecimento dos habitualmente vistos como passivos usuários das descobertas científicas, que neste caso contribuíram decisivamente para a construção coletiva de alternativas de combate a uma doença das plantações de cacau. Uma vez estabelecido o canal de comunicação, pesquisadores de instituições acadêmicas reconheceram e se dispuseram a examinar práticas agrícolas que se mostraram eficazes contra a doença, vencendo assim o abismo entre produtores e consumidores de conhecimento, e economizando pelo menos quatro anos de trabalho até chegarem a propostas semelhantes (Pereira, 2006). 
A lista expôs dúvidas, divergências e desconfianças que a autoridade tradicional, a Ceplac, por meio de abordagens unilaterais de comunicação, tentava evitar, mas que afloraram em 2008. Diferentemente da abordagem anterior, em que a Ceplac decidia pelos produtores o que fazer e os produtores apenas obedeciam, a lista ofereceu um mecanismo mais refinado de fluxo de informações, por meio do qual os produtores de cacau podiam reconhecer e expressar suas dúvidas e interesses, participar do debate e da produção de conhecimento e eles próprios decidirem o que fazer, com autonomia. $\mathrm{O}$ fato de um pesquisador acadêmico de uma universidade paulista ter coordenado os debates serviu para dar mais consistência e direção aos debates, ao mesmo tempo em que alimentava a desconfiança em relação a abordagens incomuns de manejo agrícola.

A busca por novas formas de combate à vassoura-de-bruxa indica que as instituições de pesquisa podem não ser protagonistas o tempo todo. Ao mesmo tempo, expõe os benefícios que os coordenadores de grupos de pesquisa podem obter quando decidem correr riscos e interagir com os grupos que lidam diretamente com os problemas que constituem o objeto de investigação científica. Essa experiência sugere que modelos horizontais e integrados de organização podem ser mais eficazes na formulação de respostas do que aqueles hierárquicos e lineares.

A convergência de interesses, já que todos desejavam encontrar saídas para a crise da cacauicultura, ajudou a canalizar os esforços em uma só direção e a evitar conflitos, como os que impediram as instituições de pesquisa de chegar a um consenso com os órgãos públicos, a respeito da importação de um vírus que permitiria o início dos estudos para deter uma doença que abatia o gado na Austrália nos anos 90 (Scott, 1991). Foi a busca de objetivos comuns que levou à incorporação da lista do cacau, que não deve necessariamente se tornar um elemento indispensável das redes de pesquisa. Certamente há outros meios de agregação, como os Clubes 
de Amigos da Terra (CATs), mas o que ela representa - um ambiente aberto de debate e apresentação de idéias e demandas - pode ser valioso para as descobertas andarem mais depressa e com mais firmeza e chegarem logo aos seus usuários. É estratégica, também, por ter estabelecido alianças, uma linguagem comum e o diálogo entre grupos distintos de atores distintos, mas com interesses em comum, facilitando a busca de soluções para a crise da cacauicultura. Sem a lista, as medidas de Sampaio chegariam aos outros produtores mais lentamente e possivelmente sem tanta credibilidade.

O acompanhamento das mensagens trocadas entre os participantes da lista do cacau entre agosto e outubro de 2006 indica que a lista do cacau se tornou um meio de comunicação multipropósito. Além de expor soluções técnicas, distribui as notícias sobre cacau veiculadas em jornais, revistas e websites, debate as perspectivas de novos negócios, a exemplo do cacau fino e do turismo nas fazendas de cacau, coordena ações de apoio ou repúdio a novas leis sobre o cacau e acompanha os movimentos mais importantes ligados a essa atividade econômica, como a Comissão Parlamentar de Inquérito (CPI) que investiga os detalhes da introdução do fungo da vassoura-de-bruxa no sul da Bahia, e a Câmara Setorial criada no Ministério da Agricultura para examinar a possibilidade de refinanciamento da dívida dos cacauicultores.

\section{Fungi, farmers and scientists fighting witch's broom disease}

\section{Abstract}

This article describes the interaction between producers of cocoa and academic researchers, research funding agencies and non-human actors such as fungi along the spread and the attempts to contain the witch's broom disease in Bahia state, Brazil. The analysis of this case, using a constructivist approach in sociology of science, seeks to illustrate how the production of knowledge is multifaceted, occurs at the interface of different institutional spaces and passes through moments 
of resistance and conflict as it incorporates new actors and transits such spaces. A discussion list by internet emerged as a medium able to bring together diverse groups of stakeholders and promote the collective production of knowledge.

Keywords: Witch's broom disease. Cacao. Actor-Network Theory (ART). Sociology of Science.

\section{Referências}

BAHIAJÁ. Nova tecnologia para combater a vassoura de bruxa é disseminada. Bahia Já, Ilhéus, 28 fev. 2008. Disponível em: <http://www.bahiaja.com.br/noticia. php?idNoticia $=6854>$. Acesso em: 5 dez. 2008.

BRITO, Ronildo. Sindicato Patronal Rural de Itamaraju realiza com sucesso o 1o encontro para erradicação da vassoura-de-bruxa. Rádio Extremo Sul, Itamaraju, 25 abr. 2008. Disponível em: <http://www.extremosulam.com.br/news/index. php?id=1506\&sess=0>. Acesso em: 5 dez. 2008.

CALLON, Michel. Some elements of a sociology of translation: domestication of the scallops and fishermen of St. Brieuc Bay. In: LAW, John (Org.). Power, Action and Belief: a new sociology of knowledge? London: Routledge, 1986. p. 196233.

CAMARGO, Anamaria; SIMPSON, Andrew. Collaborative research networks work. Journal of Clinical Investigation, Nova York, v. 112, n. 4, p. 468-471, ago. 2003.

COMISSÃO EXECUTIVA DO PLANO DA LAVOURA CACAUEIRA, 2008a. Resistência Induzida - Método prático. Disponível em: < http://www.ceplac.gov.br/ Noticias/200804/not00821.htm>. Acesso em: 05 dez. 2008.

COMISSÃO EXECUTIVA DO PLANO DA LAVOURA CACAUEIRA, 2008b. Nota à Imprensa: acerca da indução de resistência de cacaueiros à vassoura-de-bruxa pela aplicação de sacarose. Disponível em: <http://www.ceplac.gov.br/restrito/ lerNoticia.asp?id=1292>. Acesso em: 05 dez. 2008.

COIMBRA, Ubervalter. Nova técnica para tratar cacau protegerá mata nativa no ES. Século, Vitória, 2 jun. 2008. Disponível em: < http://www.seculodiario.com. br/arquivo/2008/junho/02/noticiario/meio_ambiente/02_06_06.asp >. Acesso em: 05 dez. 2008.

COLLINS, Peters. Brazilian Science Fruits of Co-operation. The Economist, Londres, 22 jul. 2000. 
DIAS, Elaine. Redes de Pesquisa em Genômica no Brasil: políticas públicas e estratégias privadas frente a programas de seqüenciamento genético. 2006. $225 \mathrm{f}$. Dissertação (Mestrado em Política Científica e Tecnológica) - Instituto de Geociências, Universidade Estadual Paulista, Campinas, 2006.

EKBOIR, Javier. Developing No-Till Packages for Small-Scale Farmers. In: EKBOIR, Javier (Org.). World Wheat Overview and Outlook 2000-2001. Cidade do México: CIMMYT, 2002. p. 1.

EKBOIR, Javier. Innovation Systems and Technology Policy: Zero Tillage in Brazil. Research Policy, Amsterdan, v. 32, n. 4, p. 573-586, abr. 2003.

FIORAVANTI, Carlos. A vassoura varrida. Pesquisa Fapesp, São Paulo, out. 2006. GIBBONS, Michael et al. The new production of knowledge: the dynamics of science and research in contemporary societies. London, England: Sage Publications, 2000.

GOMES, Aimberê. Itamaraju: Ceplac ensina o método da indução. Sul Bahia News, Itamaraju, 3 jun, 2008. Disponível em: < http://www.sulbahianews.com.br/ ler.php?doc $=295 .>$ Acesso em: 05 dez. 2008.

HARTMANN, Thomas. O setor produtor de cacau no Brasil em 2007. Boletim da Associação dos Produtores de Cacau, Ilhéus, 13 abr. 2008. Disponível em: < http://www.apcacau.com/index.php?option=com_content\&task=view\&id=19\&lt emid=2.> Acesso em: 09 dez. 2008.

KNORR-CETINA, Karen; MULKAY, Michael. Science Observed. Perspectives on the Social Study of Science. London: Sage, 1985.

LATOUR, Bruno. Give me a Laboratory and I will Raise the World. In: KNORRCETINA, Karen; MULKAY, Michael (Orgs.). Science Observed. Perspectives on the Social Study of Science. London: Sage, 1985, p. 141-170.

LATOUR, Bruno. Ciência em Ação: como seguir cientistas e engenheiros sociedade afora. São Paulo: Editora Unesp, 2000.

LATOUR, Bruno. Reassembling the social: an introduction to Actor-NetworkTheory. Oxford: Oxford University Press, 2005.

MEINHARDT, Lyndel et al. Moniliophthora perniciosa, the causal agent of witches' broom disease of cacao: what's new from this old foe? Molecular Plant Pathology, Londres, v. 9, n. 5, p. 577-588, set. 2008.

MEINHARDT, Lyndel et al. In vitro production of biotrophic-like cultures of Crinipellis perniciosa, the causal agente of witches's broom disease of Theobroma сасаo. Current Microbiology, Nova York, v. 52, n. 3, p. 191-196, mar. 2006. 
MELO, Beth. Bahia vence pior doença do cacau. Estado de São Paulo, suplemento agrícola, São Paulo, 15 mar. 2007. Disponível em: <http://www.seagri.ba.gov. br/noticias.asp?qact=view\&notid=9466. $>$ Acesso em: 09 dez. 2008.

MONDEGO, Jorge et al. A genome survey of Moniliophthora perniciosa gives new insights into Witches' Broom Disease of cacao. BMC Genomics, Londres, v. 9, n. 549, nov. 2008.

OLIVEIRA, Ana. Técnica induz o cacaueiro a resistir mais contra fungo. A Tarde, Salvador, 17 fev. 2008. Disponível em: < http://www.seagri.ba.gov.br/noticias. asp?qact $=$ view\&notid=13711>. Acesso em: 05 dez. 2008.

PEREIRA, Gonçalo. Comunicação pessoal, 2006.

ROHTER, Larry. Model for Research Rises in a Third World. The New York Times, Nova York, 24 abr. 2001.

SAMPAIO, Edvaldo. O sonho de um cacauicultor. Salvador: Editora do autor, 2008.

SCARPARI, Leandra et al. Biochemical changes during the development of witches' broom: the most important disease of cocoa in Brazil caused by Crinipellis perniciosa. Journal of Experimental Botany, Oxford, v. 56, n. 413, p. 865-877, mar. 2005.

SANTOS, Cristina; OLIVEIRA, Ana. Técnica dribla vassoura-de-bruxa. A Tarde, Salvador, 30 set. 2005. Disponível em: < http://www.atarde.com.br/economia/ noticia.jsf?id=515661>. Acesso em: 08 mar. 2010.

SCOTT, Pam. Levers and Counterweights: a laboratory that failed to raise the world. Social Studies of Science, Londres, v. 21, n. 1, p. 7-35, fev. 1991.

SIMPSON, Andrew et al. The genome sequence of the plant pathogen Xylella fastidiosa. Nature, Londres, v. 406, n. 6792, p. 151-157, 2000.

ZUGAIB, Antonio et al. Mercado de Cacau. Disponível em: < http://www.ceplac. gov.br/radar/mercado_cacau.htm > . Acesso em: 27 set. 2007.

Recebido: 25/03/2010

Aceite final: 25/11/2010 